\title{
ANALISIS MOTIVASI KONSUMEN DALAM PROSES KEPUTUSAN PEMBELIAN BUSANA SYAR'I TERHADAP MAHASISWA MANAJEMEN 2016 FAKULTAS EKONOMI DAN BISNIS UNIVERSITAS MUHAMMADIYAH MAKASSAR
}

\author{
Agus Salim HR \\ agussalimhr@unismuh.ac.id \\ Fakultas Ekonomi dan Bisnis \\ Universitas Muhammadiyah Makassar \\ Sulaeman Masnan \\ sulaemanmasnan@unismuh.ac.id \\ Fakultas Ekonomi dan Bisnis \\ Universitas Muhammadiyah Makassar \\ Mardiah \\ mardiah@gmail.com \\ Fakultas Ekonomi dan Bisnis \\ Universitas Muhammadiyah Makassar
}

\begin{abstract}
This study aims to determine and analyze the motivation of consumers in the process of shariah clothing purchase decisions in management students of the 2016 Faculty of Economics and Business, University of Muhammadiyah Makassar. The type of research used is qualitative, using interview techniques, observation and documentation. Based on the results of research from the analysis that has been carried out, it can be concluded that several things can be motivated by Management Students 2016 Faculty of Economics and Business on the decision to purchase sharia clothing, namely; Introducing needs, information seeking, alternative evaluations, purchasing decisions, and post-purchase behavior.
\end{abstract}

Keywords :Consumer motivation, purchasing decisions.

\begin{abstract}
Abstrak
Penelitian ini bertujuan untuk mengetahui dan menganalisis motivasi konsumen dalam proses keputusan pembelian busana syar"i pada mahasiswa manajemen angkatan 2016 Fakultas Ekonomi dan Bisnis Unversitas Muhammadiyah Makassar.Jenis penelitian yang digunakan yaitu kualitatif, dengan menggunakan teknik wawancara, observasi dan dokumentasi. Berdasarkan hasil penelitian dari analisis yang telah dilaksakan maka dapat maka dapat diambil kesimpulan beberapa hal yang menjadi motivasi Mahasiswa Manajemen 2016 Fakultas Ekonomi dan Bisnis terhadap keputusan pembelian busana syar"i yaitu; Pengenalan kebutuhan, pencarian informasi, evaluasi alternatif, keputusan pembelian, danperilaku pasca pembelian.
\end{abstract}

Kata Kunci :Motivasi konsumen, Keputusan pembelian 


\section{PENDAHULUAN}

Persaingan antar pasar industri pakaian semakin kompetitif. Hal ini terbukti dengan banyaknya jenis pakaian produksi dalam negeri dan produksi luar negeri yang beredar di Indonesia. Membanjirnya model pakaian di pasaran mempengaruhi minat seseorang terhadap pembelian dan berdampak kepada proses keputusan pembelian. Pembelian pakaian bukan lagi untuk memenuhi keinginan saja, melainkan karena pakaian adalah sebuah kebutuhan. Manusia selalu mengalami perubahan selama hidup baik secara individu maupun secara kolektif dalam konteks kehidupan bermasyarakat (Soekanto, 2006:259).

Perubahan dalam berbagai macam sektor yang terjadi pada kelompok masyarakat disebut sebagai perubahan sosial. Perubahan sosial dapat dilihat dari perkembangan zaman saat ini, mulai dari teknologi, transportasi hingga ke fashionable yang mengalami perkembangan cukup pesat dan serba modern. Fashionable muslim pun tidak kalah, semakin hari semakin banyak model busana muslim baru dan dapat dinikmati seluruh masyarakat muslim. Indonesia merupakan negara yang mayoritas penduduknya adalah muslim. Walaupun muslim menjadi mayoritas, namun Indonesia bukan Negara yang berasaskan Islam. Sebagai wanita muslim tentu harus memperhatikan cara berpakaian yang berkaitan dengan nilai agama. Salah satu hal yang sering menjadi pusat perhatian adalah cara mengenakan busana.

Hal ini berpengaruh dengan semakin banyak wanita muslim yang menggunakan busana syar"i, pemakaian busana yang dulunya hanya untuk menutupi aurat, sekarang beralih menjadi trend fashion untuk tampil modis dan trendy namun tetap dalam syariat Islam. Hal ini dibuktikan dengan berkembangnya gaya berbusana wanita berjilbab yang semakin bervariasi dan model berjilbabnya pun beragam. Fenomena ini memberikan peluang bisnis baru di Indonesia, diantaranya bisnis busana muslim dan jilbab yang saat ini semakin berkembang pesat sehingga muncul merek-merek baru. Model busana syar"i yang dibuat para desainer saat ini semakin cantik, modis dan trendy, berbeda dengan jaman dahulu.

Sekarang ini mudah dijumpai model busana syar"i dengan aneka bentuk dan motif yang cantik. Pakaian busana pun mulai beragam, unik dan tampak modern. Islam pun menganggap cara berbusana sebagai tindakan ibadah dan merupakan cerminan seorang umat. Islam telah menetapkan syarat-syarat bagi busana muslimah dalam kehidupan umum, seperti yang ditunjukkan oleh nash-nash Al-Quran dan AlSunnah. Di antara syarat untuk berbusana muslimah tidak boleh menggunakan bahan yang transparan atau yang menampakkan lekuk tubuh perempuan.

Fenomena sekarang ini tidak sesuai dengan apa yang diharapkan, ada sebagian wanita muslim yang hanya memakai jilbab atau busana muslim pada situasi-situasi tertentu, tetapi tidak memakai jilbab atau busana muslimah pada situas lainnya. Salah satu kampus Islam di Makassar yaitu Universitas Muhammadiyah Makassar merupakan lembaga pendidikan yang menerapkan ajaran Islami. Dalam bidang pengetahuan, Universitas Muhammadiyah Makassar dilandasi pada ilmu agama Islam. 
Begitu pula dalam hal etika Universitas Muhammadiyah Makassar mewajibkan seluruh mahasiswinya untuk menggunakan busana muslimah dan jilbab. Perkembangan bisnis busana muslim khususnya toko-toko busana syar"i di Kota Makassar sangat pesat, hal ini dapat dilihat dari banyak bermunculan toko-toko hijab di Kota Makassar. Sehingga, persaingan pada bisnis ini menjadi semakin cukup ketat dan setiap toko berlomba-lomba untuk memberikan harga yang murah namun kualitas yang bagus dan memberikan pelayanan yang terbaik kepada konsumen.

Keputusan pembelian merupakan suatu konsep dalam perilaku pembelian dimana konsumen memutuskan untuk bertindak atau melakukan sesuatu dan dalam hal ini melakukan pembelian ataupun memanfaatkan produk atau jasa tertentu. Pengambilan keputusan konsumen pada dasarnya merupakan proses pemecahan masalah. Peneliti menggunakan variabel keputusan pembelian ini karena studi tentang keputusan pembelian masih layak untuk diteliti mengingat semakin banyaknya produk yang beredar mengakibatkan perlunya berbagai pertimbangan bagi masyarakat dalam melakukan keputusan pembelian.

Kebanyakan konsumen, baik konsumen individu maupun pembeli organisasi melalui proses mental yang hampir sama dalam memutuskan produk dan merek apa yang akan dibeli. Keputusan pembelian konsumen dapat dilakukan apabila produk tersebut sesuai dengan apa yang diinginkan dan dibutuhkan konsumen.

\section{TINJAUAN PUSTAKA}

a. Motivasi

Motivasi adalah suatu usaha yang disadari untuk mempengaruhi tingkah laku seseorang agar ia tergerak hatinya untuk bertindak melakukan sesuatu sehingga mencapai hasil atau tujuan tertentu (Purwanto, 2007: 73). Motivasi merupakan dorongan, hasrat, kebutuhan seseorang untuk melakukan aktivitas tertentu dalam hal ini motivasi untuk belajar. Motivasi pada hakikatnya merupakan faktor rangsangan yang terjadi baik secara internal maupun eksternal yang datang dari luar, yang selanjutnya akan menyebabkan manusia mengalami rangsangan atau dorongan dan kemudian bersikap dan berperilaku.

Menurut Handoko (2001: 225) mengatakan bahwa motivasi adalah suatu keadaan dalam pribadi yang mendorong keinginan individu untuk melakukan keinginan tertentu guna mencapai tujuan. Sedangkan dalam bidang pemasaran Sigit (2002: 17) menjelaskan bahwa motivasi pembelian adalah pertimbangan pertimbangan dan pengaruh yang mendorong orang untuk melakukan pembelian. Motivasi juga dapat dianggap sebagai disposisi nilai seseorang, yang jika telah terbentuk secara relatif dapat bertahan walaupun masih ada kemungkinan untuk dimodifikasi. Sedangkan proses motivasi merupakan interaksi antara motivasi dengan aspek-aspek situasi yang relevan (Heckhausen, 1988:17-18).

Menurut Setiadi (2003: 43) motivasi konsumen adalah keadaan di dalam pribadi seseorang yang mendorong keinginan individu untuk melakukan kegiatan-kegiatan guna mencapai suatu tujuan. Adanya motivasi pada diri seseorang akan menunjukkan suatu perilaku yang diarahkan pada suatu 
tujuan untuk mencapai sasaran kepuasan. Beberapa definisi sebelumnya dapat disimpulkan bahwa motivasi muncul karena kebutuhan yang dirasakan oleh konsumen. Kebutuhan sendiri muncul karena konsumen merasakan ketidaknyamanan (state of tension) antara yang seharusnya dirasakan dan yang sesunguhnya dirasakan. Kebutuhan yang dirasakan tersebut mendorong seseorang untuk melakukan tindakan memenuhi kebutuhan tersebut (Sumarwan, 2004: 38). Motivasi muncul karena adanya kebutuhan yang dirasakan

\section{b. Keputusan Pembelian}

Pengambilan keputusan dapat dianggap sebagai suatu hasil atau keluaran dari proses mental atau kognitif yang membawa pada pemilihan suatu jalur tindakan di antara beberapa alternatif yang tersedia. Setiap proses pengambilan keputusan selalu menghasilkan satu pilihan final. Keluarannya bisa berupa suatu tindakan (aksi) atau suatu opini terhadap pilihan. Menurut James A. F. Stoner pengambilan keputusan adalah proses yang digunakan untuk memilih suatu tindakan sebagai cara pemecahan masalah.

$\begin{array}{llr}\begin{array}{c}\text { Menurut } \\ \text { pengambilan }\end{array} & \text { keputusan } & \begin{array}{r}\text { Terry } \\ \text { adalah }\end{array}\end{array}$
pemilihan alternatif perilaku (kelakuan) tertentu dari dua atau lebih alternatif yang ada. Dari definisi yang telah di jelaskan dapat disimpulkan bahwa pengambilan keputusan itu adalah suatu cara yang digunakan untuk memberikan suatu pendapat yang dapat menyelesaikan suatu masalah dengan cara/teknik tertentu agar dapat lebih diterima oleh semua pihak. Keputusan pembelian merupakan suatu konsep dalam perilaku pembelian dimana konsumen memutuskan untuk bertindak atau melakukan sesuatu dan dalam hal ini melakukan pembelian ataupun memanfaatkan produk atau jasa tertentu. Pengambilan keputusan konsumen pada dasarnya merupakan proses pemecahan masalah.

Dalam melakukan keputusan pembelian biasanya hal pertama yang dipertimbangkan konsumen dalam memilih produk adalah dengan melihat atribut produk. Atribut produk memiliki dua peran yang sangat penting bagi konsumen dalam melakukan keputusan pembelian. Dalam sebuah produk pasti terdapat unsur-unsur atribut produk yang dapat mempengaruhi konsumen dalam melakukan keputusan pembelian yaitu kualitas produk, harga, merek, dan fitur. Hal tersebut menjadi bahan pertimbangan paling utama bagi konsumen sebelum melakukan keputusan pembelian pada suatu produk.

\section{METODE PENELITIAN}

\section{a. Jenis Penelitian}

Jenis penelitian yang digunakan yaitu kualitatif. Metode penelitian kualitatif menurut Patton (Ahmadi, 2014: 5-6) adalah metode yang digunakan untuk memahami fenomena yang terjadi secara alamiah (natural) dalam keadaankeadaan yang sedang terjadi secara alamiah.

\section{b. Fokus Penelitian}

Penelitian ini memfokuskan pada apa yang menjadi dorongan atau motivasi konsumen dalam proses keputusan pembelian busana syar"i pada mahasiswa manajemen 2016 Fakultas Ekonomi dan Bisnis Universitas Muhammadiyah Makassar. 


\section{c. Teknik Pengumpulan Data}

1) Wawancara

Wanwancara adalah percakapan anatara dua atau lebih dan berlangsung antara narasumber dan pewawancara. Menurut Lexy J. Moleong, wawancara adalah suatu percakapan dengan tujuantujuan tertentu. Pada metode ini peneliti dan responden berhadapanlangsung (face to face) untuk mendapatkan informasi secara lisan dengan tujuan mendapatkan data yang dapat menjelaskan permasalahan penelitian. Dalam hal ini metode wawancara yang penulis gunakan adalah metode wawancara terstruktur, yaitu pedoman wawancara yang telah dirumuskan dengan cermat sehingga dalam wawancara menjadi lancar dan tidak kaku.

\section{2) Observasi}

Observasi berasal dari kata to observe yang artinya mengamati, tujuannya pemahaman atau pembuktian terhadap informasi atau keterangan yang diperoleh sebelumnya. Tujuan dari observasi adalah mendiskripsikan aktivitas yang berlangsung, dan orang yang terlibat dalam kegiatan yang diamati tersebut. Dalam penelitian ini, observasi dilakukan dengan mengamati cara berpakaian pada mahasiswa manajemen 2016 universitas muhammadiyah Makassar.

\section{3) Dokumentasi}

Dokumentasi adalah semua jenis rekaman atau catatan sekunder lainnya seperti surat-surat, memo, dan foto-foto. Hasil penelitian dari wawancara dan observasi akan lebih dipercaya bila didukung dengan dokumentasi.

\section{d. Instrumen Penelitian}

Instrumen penelitian merupakan suatu unsur yang sangat penting dalam suatu penelitian, karena fungsinya sebagai sarana pengumpul data yang banyak menentukan keberhasilan suatu penelitian yang dituju. Oleh karena itu, instrumen yang digunakan harus disesuaikan dengan situasi dan kondisi dari penelitian itu sendiri. Adapun alatalat penelitian yang digunakan peneliti dalam melakukan penelitian sebagai berikut : pedoman wawancara, pedoman observasi, handphone dan alat tulis

\section{e. Teknik Analisis Data}

Teknik analisis data yang digunakan dalam penelitian ini adalah analisis kualitatif. Sebagaimana yang diungkapkan Miles dan hubberman (Sugiyono : 2007:204) yaitu pengumpulan data, reduksi data, penyajian data, dan langkah terakhir adalah penarikan kesimpulan. Langkahlangkah tersebut adalah sebagai berikut: Reduksi data, penyajian data, dan penarikan kesimpulan.

\section{HASIL PENELITIAN}

a. Penyajian Data

Narasumber adalah Mahasiswa Manajemen $2016 \quad$ Universitas Muhammadiayah Makassar yang menggunakan busana syar"i. Jumlah Mahasiswa Manajemen 2016 ada 364 orang yang terbagi dalam 10 kelas, dan orang yang berbusana syar"i paling sedikit $2-5$ orang per kelas. Peneliti mengambil 50 mahasiswa manajemen 2016 fakultas ekonomi dan bisnis Universitas Muhammadiyah Makassar untuk di jadikan narasumber sebagai sumber data utama dalam penelitian ini. 


\section{b. Motivasi Mahasiswa Manajemen Memakai Busana Syar"i}

Berdasarakan hasil observasi peneliti bahwa semua mahasiswa manajemen angkatan 2016 menggunakan jilbab, akan tetapi tidak semua mahasiswa berbusana sesuai dengan apa yang disyariatkan. Ada yang memakai busana ketat dan transparan sehingga tidak menutupi aurat. Namun ada juga yang memakai busana syar"i karena kesadaran keagamaam, pengaruh lingkungan, bahkan hanya mengikuti trend.

Feni salah satu narasumber yang mengungkapkan motivasinya memakai busana syar"i berikut ini. Saya memakai busana syar"i karena saya sadar sebagai seorang muslimah kita wajib menutup aurat dengan menggunakan pakaian yang sesuai dengan aturan agama Islam, oleh karena itu saya termotivasi untuk memakai busana syar"i. Ungkapan yang sama juga diutarakan oleh saudari Ani sebagai berikut. Saya memakai busana syar"i karena kesadaran keagamaan yang pada dasarnya memerintahkan kita untuk menutup aurat.

Selanjutnya ungkapan dari saudari Anita mengenai motivasi dia memakai busan syar"i sebagai berikut. Motivasi saya memakai busana syar"i karena saya sadar bahwa sebagai seorang muslimah yang baik kita diwajibkan untuk mengunnakan pakaian yang sesuai dengan atauran agama. Berdasarkan hasil wawancara di atas dapat disimpulkan bahwa salah satu alasan mahasiswa manajemen memakai busana syar"i karena kesadaran keagamaan.

Pendapat yang lain dari salah satu mahasiswa manajemen yang diungkapkan sebagai berikut. "Saya memakai busana syar" karena termotivasi dari lingkungan kampus yang mana mahasiswanya banyak memakai busana syar"i sehinnga saya juga tertarik untuk memakai busana tersebut".

Selanjutnya pendapat yang hampir sama juga diutarakan ole saudari adhe yang diungkapkan sebagai berikut."Saya termotivasi untuk memakai busana syar"i karena melihat teman-teman saya banyak yang memakainya, sehingga saya pun ikut mencoba memakai busana syar"i".

Berdasarkan hasil wawancara tersebut dapat diketahui bahwa salah satu alasan mahasiswa manajemen memakai busana syar"i karena pengaruh dari lingkungan sekitar.

\section{c. Analisis Motivasi Konsumen terhadap Proses Keputusan Pembelian Busana Syar"i}

Berdasarkan hasil observasi peneliti bahwa sebagian besar Mahasiswa Manajemen 2016 yang menjadi Informan memilih untuk tidak membeli busana syar"i dan sebagian kecil mahasiswa Manajemen 2016 memilih busana syar"i dikarenakan sebagian trend busana yang berkembang di masyarakat itu tidak sesuai dengan syariat Islam yang diperbolehkan.

Hasil wawancara dengan responden mengenai motivasi spembelian busana syar"i seperti yang dikatakan oleh saudari Eka sebagai berikut. "Menurut saya dalam berbusana kita tetap harus memperhatikan syari"at, sehingga tidak bertolak belakang dengan apa yang aturan islam. Motivas saya membeli busana syar"i ini karena saya merasa nyaman dan aman pada saat memakai busana syar"i".

Pendapat yang senada juga diungkapkan oleh sudari Ayu sebagai berikut. "Motivasi saya membeli busana 
syar"i karena saya merasa nyaman saat menggunakan busana syar"i, dari unjung kepala sampai ujung kaki semua terlindungi oleh busana tersebut".

Selanjutnya ungkapan yang sama juga dinyatakan oleh saudari Nova sebagai berikut. "Motivasi saya membeli busana syar"i karena pada saat saya memakainya saya merasa nyaman dan saya merasa terlindungan dengan pakaian ini".

Berdasarkan hasil wawancara tersebut dapat disimpulkan bahwa pendapat mereka sejalan dengan teori motivasi Abraham H. Maslow bahwa salah satu hierarki kebutuhan manusia yaitu kebutuhan rasa aman (safty needs).

Berdasarkan hasil wawancara tersebut dapat diketahui bahwa pendapat tersebut sejalan dengan teori motivasi menurut Sigit tentang motivasi rasional. Motivasi Rasional adalah pembelian yang didasarkan kepada kenyataan-kenyataan yang ditunjukkan oleh produk kepada konsumen dan merupakan atribut produk yang fungsional serta objektif keadaannya misalnya kuliatas produk, harga produk, ketersediaan barang, efesiensi kegunaan barang tersebut dapat diterima.

\section{d. Keputusan Pembelian Busana Syar"i}

Berdasarkan hasil wawancara dengan salah satu mahasiswa manajemen yang bernama Vivi memberikan ungkapan sebagai berikut. "Sebagai orang yang memakai busana syar"i, kebutuhan akan pakaian mendorong saya untuk membeli busana syar"i yang dapat saya gunakan ke kampus atau di luar kampus".

Ungkapan yang hampir sama juga diutarakan oleh saudari Reski berikut ini. "Semenjak kuliah d unismuh, kebutuhan akan pakaian mendorong saya untuk membeli busana syar"i yang dapat saya kenakan ke kampus".

Berdasarkan wawancara yang dilakukan dengan saudari Yuli berikut ini. "Awalnya saya tidak tertarik untuk membeli busana syar"i, tetapi setelah melihat iklan dan promosi di sosial media banyak olshop yang menawarkan busana syar"i dengan model dan kuliatas yang bagus sehingga saya mulai tertarik untuk membeli busana syar"i".

Saudari Uni juga berpendapat demikian seperti yang diungkapkan berikut ini. "Iklan di sosial media menjadi daya tarik tersendiri untuk saya dalam membeli busana syar"i karena banyak pilihan yang ditawarkan".

Dari hasil wawancara tersebut dapat diketahui bahwa faktor internal dan eksternal berbengaruh terhadap proses keputusan pembelian busana syar"i, seperti yang dinyatakan oleh Kotler bahwa rangsangan internal dan rangsangan eksternal berpengaruh terhadap keputusan pembelian.

Proses pembelian diawali dengan pengenalan masalah atau kebutuhan. Kebutuhan dapat timbul ketika pembeli merasakan adanya rangsangan eksternal atau internal yang mendorong dirinya untuk mengenali kebutuhan. Rangsangan internal timbul dari dalam diri manusia itu sendiri, sedangkan dorongan eksternal berasal dari luar diri manusia atau lingkungan.

Seperti yang dinyatakan oleh saudari Nurul Sumber pribadi yang berasal dari keluarga, teman, tetangga, dan lingkungan sekitar mempengaruhi keputusan pembelian konsumen, berikut hasil wawancaranya. "Pada saat saya ingin membeli busana syar"i terlebih dahulu saya tanyakan kepada keluarga atau teman, karena jika hanya 
mengandalkan iklan di media sosial takutnya nanti tidak sesuai dengan apa yang diharapakan".

Selanjutnya pendapat yang dikemukan oleh saudari Devi seperti ungkapannya berikut ini. "Ketika saya ingin membeli busana syar"i terlebih dahulu saya tanyakan kepada ibu atau teman, karena jika hanya mengandalkan iklan di media sosial belum menajamin kualitas barangnya".

Pendapat yang senada juga dikemukan oleh saudari Rini seperti ungkapannya berikut ini. "Sebelum saya membeli busana syar"i terlebih dahulu saya meminta pendapat kepada keluarga atau teman, karena saya belum mempercayai barang yang ditawarkan di media sosial sepenuhnya".

Berdasarkan hasil wawancara di atas dapat disimpulkan bahwa pencarian informasi merupakan proses tahapan pengambilan keputusan pembeli dimana konsumen telah tertarik untuk mencari lebih banyak informasi.

Berdasarkan semua hasil wawancara di atas dapat diketahui bahwa sumber pencarian informasi berpengaruh pada keputusan pembelian busana syar"i dan sesuai dengan apa yang dinyatakan oleh Kotler yang menggolongkan sumber informasi konsumen ke dalam empat kelompok yaitu, sumber pribadi, sumber, sumber komersial, sumber publik, dan sumber pengalaman.

Menurut saudari Ulfi evaluasi alternatif berpengaruh terhadap keputusan pembelian busana syar,i seperti pendapatnya berikut ini. "Saya kuliah di Unismuh Makassar yang pada dasarnya menerapakan atauran dalam berbusana. Saya merasakan manfaat dari bbusana syar"i ini karena dapat saya kenakan ke kampus".
Hal yang senada juga diungkapkan oleh saudari Indra sebagai berikut. "Sebagai mahasiswa Unismuh Makassar yang berlandaskan Agama Islam, saya manfaat dari busana syar"i ini karena dapat memenuhui aturan kampus".

Dari hasil wawancara tersebut bahwa evaluasi alternatif merupakan salah satu motivasi konsumen dalam keputusan pembelian busana syar" $i$ karena mereka merasa kebutuhannya terpenuhi dan mendapatkan manfaat dari membeli busana syar"i. Hal ini sesuai dengan apa yang dinyatakan oleh Kotler.

Menurut saudari Hikma mengenai keputusan pembelian busana syar" $\mathrm{i}$ sebagai berikut. "Saya mengambil keputusan membeli busana syar"i karena motivasi dari diri sendiri yang sebelumnya sudah dipikirkan secara matang sehingga pada akhirnya memutuskan untuk membelinya".

Sedangkan menurut saudari Reni sebelum mengambil keputusan pembelian dia sering mempertimbangkan masukan dari seseorang seperti ungkapannya berikut ini. "Sebelum saya mengambil keputusan dalam pembelian busana syar"i saya terlebih dahulu meminta tanggapan dari keluarga dan teman-teman yang sudah terlebih dahulu memakai busana syar"i". Berdasarkan hasil wawancara tersebut dapat disimpulkan bahwa dalam pengambilan keputusan pembelian busana syar"i telah sesuai dengan apa yang dinyatakan oleh Kotler yang menyatakan bahwa keputusan pembelian dipengaruhi oleh motivasi pribadi ataupun pengaruh dari orang lain.

Menurut saudari Yuni bahwa ketika ia mengetahui ada produk yang lebih bagus dari yang ia beli maka merasa 
sedikit terganggu, seperti pemaparannya berikut ini. "Pada saat saya sudah membeli busana syar"i tetapi muncul lagi model terbaru dengan harga yang sama maka saya sedikit terganggu".

Pernyataan saudari Yuli juga didukung oleh saudari Lia yang mengungkapkan hal berikut. "Apabila saya telah membeli busana syar"i tetapi ternyata ada busana syar"i yang memiliki kuliatas yang lebih baik dengan harga yang hampir sama maka saya merasa terganggu".

Berdasarkan tanggapan responden tersebut dapat disimpulkan bahwa kosumen akan merasa terganggu dengan adanya produk yang lebih baik dibanding dengan produk yang telah dibelinya seperti kualitasnya yang lebih baik atau harganya yang lebih murah. Hal ini sesuai dengan apa yang dinyatakan oleh Kotler bahwa konsumen akan mengalami level kepuasan atau ketidakpuasan tertentu

\section{DAFTAR PUSTAKA}

Indayani, K., Kirya, I. K., Yulianthini, N. N., \& SE, M. (2014). Analisis FaktorFaktor yang Mempengaruhi Keputusan Konsumen dalam Membeli Mobil. Jurnal Jurusan Manajemen, 2(1), (Online), (http://ejournal.undiksha.ac.id, diakses tanggal 20 Maret 2019).

Isa, M., Mardalis, A., \& Mangifera, L. (2018). Analisis Keputusan Konsumen Dalam Melakukan Pembelian Makanan dan Minuman di Warung Hik. Jurnal Manajemen Dayasaing, 20(1)., (Online), (http://journals.ums.ac.id, diakses tanggal 13 Maret 2019).

J. Setiadi, Nugroho, SE., MM., 2003, "Perilaku Konsumen Konsep dan Implikasi untuk Strategi dan
Penelitian Pemasaran". Jakarta: Kencana.

Juniarti, A. D. (2019). Analisis Motif Konsumen Dilihat Dari Status Perkawinan Di Wilayah Serang Dan Pandeglang. Jurnal InTent, 2(1), (Online), (http://ejournal.lppmunbaja.ac.id, diakses tanggal 19 Maret 2019).

Karina Widya, A. (2014). Pengaruh Gaya Hidup dan Motivasi Konsumen Terhadap Proses Keputusan Pembelian Kosmetik Merek Wardah (Studi Kasus Pada Wanita Berhijab di Kota Padang) (Doctoral dissertation, andalas university), (Online), (http://repo.unand.ac.id, diakses 5 Maret 2019).

Kotler, P., \& Keller,K.L. (2009). Manajemen Pemasaran (Cetakan Ketiga Belas). Jakarta: Erlangga

Nazmah, N. (2015). Motivasi Berbusana Muslimah Mahasiswi Fakultas Agama Islam Universitas Muhammadiyah Surakarta Tahun 2014 (Doctoral dissertation, Universitas Muhammadiyah Surakarta), (Online), (http://eprints.ums.ac.id, diakses tanggal 22 Maret 2019).

Sundari, Y., Harisudin, M., \& Agustono, A. (2018). Analisis Faktor-Faktor Yang Dipertimbangkan Konsumen Dalam Keputusan Pembelian Minyak Goreng Bimoli Di Pasar Swalayan Kabupaten Wonogiri. SEPA: Jurnal Sosial Ekonomi Pertanian dan Agribisnis, 15(1), 39-49, (Onine), (https://jurnal.uns.ac.id, diakses 10 Maret 2019).

Sundari, Y., Harisudin, M., \& Agustono, A. (2018). Analisis Faktor-Faktor Yang Dipertimbangkan Konsumen Dalam Keputusan Pembelian Minyak Goreng Bimoli Di Pasar Swalayan Kabupaten Wonogiri. SEPA: Jurnal Sosial Ekonomi Pertanian dan Agribisnis, 15(1), 39-49, (Online), 
(https://jurnal.uns.ac.id, diakses 15 Maret 2019).

Wahab, F., Hufron, M., \& Slamet, A. R. (2018). Pengaruh Persepsi Kualitas Dan Harga Terhadap Keputusan Pembelian Kostum Olah Raga (Studi Kasus

Pada Konsumen Jerseyzone Malang). Jurnal Ilmiah Riset Manajemen, 7(03), (Online) (http://eprints.umm.ac.id, diakses 5 Maret 2019).

Wijaya, D. N., Sunarti, S., \& Pangestuti, E. (2018). Pengaruh Gaya Hidup Dan Motivasi Terhadap Keputusan Pembelian (Survei Pada Konsumen Starbucks, Kota Malang). Jurnal Administrasi Bisnis, 55(2), (Online),

(http://administrasibisnis.studentj ournal.ub.ac.id, diakses 5 Maret 2019).

Shihab, Quraish. (2004). Pakaian Wanita Muslimah, Jakarta: Lentera Hati.

Indrawati, D. (2015). Pengaruh Citra Merek dan Gaya Hidup Hedonis Terhadap Keputusan Pembelian Jilbab "Zoya". Jurnal Riset Ekonomi dan Manajemen,15(2), (Online), (http://jrem.iseisby.or.id, diakses tanggal 27 Juli 2019).

Ain, N., \& Ratnasari, R. T. (2015). Pengaruh Citra Merek Melalui Sikap Konsumen Terhadap Niat Beli Ulang Pada Produk Busana Muslim Zoya di Surabaya. Jurnal Ekonomi Syariah Teori dan Terapan, 2(7), (Online),

(https://ejournal.unair.ac.id, diakses tanggal 27 Juli 2019).

Astika, A. (2017). Pengaruh Strategi Pemasaran Berbasis Syariah Terhadap Minat Konsumen Untuk Membeli Produk Pada Zoya Palembang.[Skripsi] (Doctoral Dissertation, Uin Raden Fatah Palembang), (Online), (http://eprints.radenfatah.ac.id, diakses tanggal 27 Juli 2019).

Maemonah, S. (2017). Pengaruh merek dan labelisasi halal terhadap keputusan pembelian produk jilbab Zoya: studi kasus pada konsumen di outlet produk jilbab Zoya Pamularsih Semarang (Doctoral dissertation, UIN Walisongo), (Online), (http://eprints.walisongo.ac.id, diakses tanggal 23 Juli 2019).

Paramitha, M. P., \& Hasib, F. F. (2015). Analisis Faktor Yang Mempengaruhi Keputusan Pembelian Konsumen Terhadap Produk Rabbani di Bunker Rabbani Pucang Surabaya. Jurnal Ekonomi Syariah Teori dan Terapan, 1(6), (Online),

(https://ejournal.unair.ac.id, diakses tanggal 23 Juli 2019). 